\title{
Encountering COVID-19 as Endocrinologists
}

\author{
Eun-Jung Rhee ${ }^{1}$, Jung Hee Kim², Sun Joon Moon ${ }^{1}$, Won-Young Lee ${ }^{1}$ \\ ${ }^{1}$ Department of Endocrinology and Metabolism, Kangbuk Samsung Hospital, Sungkyunkwan University School of Medicine; \\ ${ }^{2}$ Department of Internal Medicine, Seoul National University Hospital, Seoul National University College of Medicine, Seoul, \\ Korea
}

The world is entering an era of disaster and chaos due to coronavirus disease 2019 (COVID-19), which is caused by severe acute respiratory syndrome coronavirus 2. Since its first emergence in December 2019 in Wuhan, China, COVID-19 has swept through Asia and propagated throughout the world to Europe and North America. As of April 13, 1,773,084 people were infected and 111,652 people had died from COVID-19 globally, and new record levels of infection are being reported every day. Based on the data that have been amassed so far, the primary risk factors for a severe disease course or even mortality from COVID-19 are underlying diseases such as diabetes and hypertension. As the global prevalence of diabetes continues to increase, patients with endocrine diseases such as diabetes mellitus and those who are on long-term corticosteroid therapy due to adrenal insufficiency or hypopituitarism are at risk for a poor prognosis of COVID-19. As endocrinologists, we would like to briefly review the current knowledge about the relationship between COVID-19 and endocrine diseases and to discuss what we can do for the safety and health of our patients with endocrine diseases in this globally threatening situation.

Keywords: COVID-19; Endocrinologists; Diabetes mellitus; Adrenal insufficiency; Severe acute respiratory syndrome coronavirus 2; Endocrine system diseases

\section{INTRODUCTION}

The entire world is encountering an unexpectedly disastrous situation due to coronavirus disease 2019 (COVID-19). In December 2019, the China National Health Commission reported that cases of pneumonia with an unknown cause had been detected in Wuhan in Hubei Province. The disease then rapidly spread from Wuhan to other areas of China and throughout the world. On January 3, 2020, a novel coronavirus - severe acute respiratory syndrome coronavirus 2 (SARS-CoV-2 or 2019$\mathrm{nCoV}$ ) - with phylogenetic similarity to the SARS coronavirus (SARS-CoV), the cause of the 2003 SARS outbreak, was isolated in samples of bronchoalveolar lavage fluid from patients

Received: 16 April 2020, Revised: 19 April 2020, Accepted: 22 April 2020

Corresponding author: Won-Young Lee

Division of Endocrinology and Metabolism, Department of Internal Medicine, Kangbuk Samsung Hospital, Sungkyunkwan University School of Medicine, 29 Saemunan-ro, Jongno-gu, Seoul 03181, Korea

Tel: +82-2-2001-2579, Fax: +82-2-2001-2049, E-mail: drlwy@hanmail.net in Wuhan and was confirmed as the cause of the novel atypical form of pneumonia [1]. On March 11, 2020, the World Health Organization (WHO) declared COVID-19 a public health emergency of international concern [2].

Although the first outbreak in China subsided due to the forceful closure of the city of Wuhan by the Chinese government, carriers of the virus in the incubation period had already dispersed throughout the world, and had started to spread the disease to other continents. As of April 13, 1,773,084 people were infected and 111,652 people had died from COVID-19 globally; remarkably, the disease spread to this extent within only 84 days since the first WHO situation report was released on January 21 , at a time when there were only 282 confirmed

Copyright $\odot 2020$ Korean Endocrine Society

This is an Open Access article distributed under the terms of the Creative Commons Attribution Non-Commercial License (https://creativecommons.org/ licenses/by-nc/4.0/) which permits unrestricted non-commercial use, distribution, and reproduction in any medium, provided the original work is properly cited. 
cases of COVID-19 worldwide [3]. In the Western Pacific region, China had the highest number of COVID-19-infected people (83,597 cases and 3,351 deaths), followed by Korea, with 10,537 confirmed cases and 217 deaths. In the European region, Spain had the highest number of confirmed cases (166,019, with 16,972 deaths), followed by Italy, with 156,363 confirmed cases and 19,901 total deaths. The United States of America (USA) had the highest number of confirmed cases in the world, with 524,514 cases and 20,444 deaths, mainly in the state and city of New York. All 50 USA states are under a disaster declaration for the first time in history, which means that federal funds are allowed to be used by state and local governments during the pandemic. This disastrous pandemic is threatening the health and economic well-being of the world, in both developed and developing countries.

In this review, we would like to present a brief overview of the current knowledge on COVID-19 and its relationship with endocrine diseases, and to suggest some recommendations as endocrinologists encountering this disease.

\section{WHAT WE KNOW ABOUT COVID-19}

According to phenome sequencing, SARS-CoV-2 is a betacoronavirus of the same subgenus as SARS-CoV, with which it shares a sequence identity of approximately $80 \%$ [4]. Based on RNA sequence similarity, it is likely that the primary source is bats; however, it is not certain whether SARS-CoV-2 is transmitted directly from bats [5]. It is known that SARS-CoV-2 enters the cell via the angiotensin-converting enzyme 2 (ACE2) receptor, similar to SARS-CoV [4]. Transmission between people is thought to occur mainly via respiratory droplets, which can travel less than roughly $2 \mathrm{~m}$, and also by touching infected surfaces. A study showed that the virus could remain viable in aerosols for more than 3 hours, meaning that the possibility of aerosol transmission cannot be excluded [6]. The clinical course of the disease varies from mild to critical, and risk factors for severe illness are advanced age, living in a nursing home or long-term care facility, chronic lung disease, serious heart conditions, an immunocompromised condition, severe obesity, diabetes, chronic kidney disease treated with dialysis, and liver disease [7].

No agent has yet demonstrated efficacy as a specific treatment for COVID-19. Several therapies, such as remdesivir (an antiviral agent), hydroxychloroquine/chloroquine (an antimalarial agent), tocilizumab (an interleukin-6 receptor inhibitor), and convalescent plasma therapy are under investigation [8-11]. Al- though many attempts are being made to develop vaccines against COVID-19, the WHO indicated in February 2020 that it expected a vaccine to become available in no earlier than 18 months [12]. As of April 8, 2020, among 115 vaccine candidates, the five most advanced candidates (mRNA-1273, Ad5$\mathrm{nCoV}$, INO-4800, LV-SMENP-DC, and pathogen-specific aAPC) were in phase 1 trials [13]. Regarding treatment, concerns have been raised regarding a possible increased risk for adverse outcomes in patients using ACE inhibitors or angiotensin receptor blockers, which can increase the expression level of ACE2 receptors [14]. However, it is not recommended to discontinue these agents due to a lack of sufficient evidence, and because doing so can also worsen cardiovascular or kidney disease $[15,16]$.

\section{PATIENTS WITH ADRENAL INSUFFICIENCY OR HYPOPITUITARISM OR WHO ARE ON LONG-TERM GLUCOCORTICOID TREATMENT}

Currently, no evidence indicates that patients with adrenal insufficiency (AI) or hypopituitarism are at an especially high risk for COVID-19 infection. However, several studies, including data from Korea, have demonstrated that AI patients have a two-fold to eight-fold higher risk for infection, which inherently increases the risk of death from COVID-19 [17-22]. In AI patients, the innate immune response (e.g., natural killer cell cytotoxicity) is impaired, thereby potentially compromising antiviral immune defense mechanisms and increasing patients' susceptibility to respiratory viral infections [23,24]. Moreover, the lifelong requirement for nonphysiological glucocorticoid replacement using currently available preparations may place AI patients at an increased risk for infectious diseases.

Infection is a condition of acute stress that triggers a cytokinemediated inflammatory response, which requires an increased dose of glucocorticoids. Since adrenal crises precipitated by infections are the major cause of death in AI patients $[25,26]$, an immediate modification of the glucocorticoid regimen, as indicated in so-called "sick day rules," should be conducted at the beginning of an infection. Whenever any AI patient presents with a cough, sputum, or fever $\left(\geq 37.5^{\circ} \mathrm{C}\right)$, which are symptoms suspicious for COVID-19, they need to immediately double or triple their daily oral glucocorticoid dose and continue the increased dose until the symptoms resolve. While doing so, patients need to consume more electrolyte-containing fluids as tolerated. If a patient's condition deteriorates, or a patient cannot 
eat due to vomiting or diarrhea, he or she should go to the hospital and immediately receive an injection of $100 \mathrm{mg}$ of hydrocortisone. Unfortunately, in Korea, hydrocortisone self-injection kits are not available. Therefore, patients should immediately present their steroid emergency card, which indicates that they are AI patients, and their leaflet with information on adrenal crisis to be shown to doctors [27], as these documents clearly describe the need to inject $100 \mathrm{mg}$ of hydrocortisone immediately, followed by continuous infusion of $200 \mathrm{mg}$ for 24 hours. Furthermore, patients are advised to obtain sufficient hydrocortisone and fludrocortisone supplementation to prepare for "sick day rules" and "social distancing" during the COVID-19 outbreak.

Chronic exogenous glucocorticoid administration, including through the topical, inhaled, oral, intra-articular, and parenteral routes, is widely used to treat various disorders. Excessive glucocorticoid use itself is associated with severe and intractable courses of viral infections due to the immunosuppressive actions of glucocorticoids [28-30]. The anti-inflammatory action of glucocorticoids may mask fever and indicators of active infection. Therefore, patients taking supraphysiological doses of glucocorticoids may be more susceptible to COVID-19, although there is still little concrete evidence regarding this issue. Furthermore, suppression of the hypothalamic-pituitary-adrenal (HPA) axis in long-term steroid users may cause symptoms of AI. The dose and duration of glucocorticoids that suppress the HPA axis have not been well established. However, patients currently receiving or with a history of prior exogenous glucocorticoid therapy exceeding $5 \mathrm{mg}$ of prednisolone or equivalent for longer than 3 months should follow the above-mentioned "sick day rules" [31]. Therefore, those patients should be monitored to detect AI symptoms at an early phase and should be prompted to modify their glucocorticoid replacement dose in order to prevent adrenal crisis and mortality.

\section{PATIENTS WITH DIABETES MELLITUS}

According to the Ninth Diabetes Atlas from the International Diabetes Federation, 463 million people in the world have diabetes [32]. The high global prevalence of diabetes makes it an especially concerning risk factor as the COVID-19 pandemic progresses. As we all know, patients with diabetes are more susceptible to infectious diseases, regardless of the source of pathogens. For example, patients with diabetes were more vulnerable to SARS and Middle East respiratory syndrome, the two previous worldwide fatal respiratory infections caused by coronaviruses in the last decades [33,34].
COVID-19 predominantly affects older men and those with comorbidities such as hypertension and diabetes [35]. In previous reports, the proportion of COVID-19 patients with diabetes ranged from $6 \%$ to $37 \%$, and diabetes was the first or second most common comorbidity (Table 1) [36-55]. A study from China reported that $17 \%$ of critically ill patients with SARSCoV-2 pneumonia at a single center in Wuhan had diabetes, and in another report analyzing 140 hospitalized COVID-19 patients, hypertension (30.0\%) and diabetes (12.1\%) were the most common comorbidities [38]. In a Korean report, among the 75 patients who died from COVID-19, 46.7\% had endocrine and metabolic diseases, such as diabetes or hypothyroidism [48]. In an Italian report, diabetes was the second most common comorbidity associated with COVID-19 next to hypertension, similar to previous reports from other countries [53].

Diabetes is associated both with the risk of COVID-19 infection and the severity of COVID-19. In a nationwide report from China analyzing 1,099 selected COVID-19 patients, patients with severe disease were more likely to have diabetes than those with non-severe disease (16.2\% vs. 5.7\%) [37]. In another report of 191 Chinese inpatients with COVID-19, more non-survivors than survivors had diabetes (31\% vs. 14\%) and in a univariate analysis, diabetes was associated with a 2.9-fold increased risk for in-hospital death, although the significance disappeared in a multivariate analysis [43]. Lastly, in a meta-analysis analyzing eight studies with data on 46,248 patients, diabetes was the second most prevalent comorbidity after hypertension, although diabetes was not a significant determinant of disease severity [54].

The mechanism that increases susceptibility to COVID-19 in patients with diabetes has not been conclusively established, but several theories have been proposed. First, expression levels of ACE2, the cellular receptor of SARS-CoV-2, are known to be increased in the lung, kidney, heart, and pancreas in rodent models of diabetes [56,57]. In a genome-wide Mendelian randomization study, diabetes was causally associated with increased lung ACE2 expression [58]. These studies support the hypothesis that patients with diabetes are especially susceptible to SARS-CoV-2 infection. In addition, some researchers have suggested that using renin-angiotensin aldosterone system blockers such as ACE inhibitors and angiotensin receptor blockers might increase the expression of ACE2 receptors, thereby increasing patients' susceptibility to SARS-CoV-2 $[59,60]$. However, as the control of comorbidities such as hypertension in patients with COVID-19 and diabetes is important for survival, and given the absence of further evidence of risk or benefit, 
Table 1. Proportion of Patients with Diabetes among COVID-19 Infected Patients

\begin{tabular}{|c|c|c|c|c|}
\hline Country/no. of patients analyzed & $\begin{array}{c}\text { Proportion of patients } \\
\text { with diabetes in the total } \\
\text { population }\end{array}$ & $\begin{array}{l}\text { Proportion of severe vs. } \\
\text { non-severe patients with } \\
\text { diabetes }\end{array}$ & Glycemic status or HbAlc levels & Reference \\
\hline Wuhan, China/99 patients & $12 / 99(12.1 \%)$ & - & $\begin{array}{l}\text { Mean glucose: } 7.4 \mathrm{mmol} / \mathrm{L} \\
52 \% \text { had hyperglycemia }(>6.1 \mathrm{mmol} / \mathrm{L})\end{array}$ & {$[36]$} \\
\hline $\begin{array}{l}\text { Wuhan, Huanan seafood marker, } \\
\text { China/41 patients }\end{array}$ & $8 / 41(20 \%)$ & $8 \%$ vs. $25 \%(P=0.16)$ & - & {$[35]$} \\
\hline Data from NHC, China/1,099 patients & $81 / 1,099(7.4 \%)$ & $\begin{array}{l}16.2 \% \text { vs. } 5.7 \% \text { (severe vs. non- } \\
\text { severe) } \\
26.9 \% \text { vs. } 6.1 \% \text { (primary } \\
\text { composite end point }{ }^{\mathrm{a}} \text { met vs. } \\
\text { unmet) }\end{array}$ & - & {$[37]$} \\
\hline Wuhan, China/ 52 critically ill patients & $9 / 52(17 \%)$ & $22 \%$ vs. $10 \%$ & Hyperglycemia in $35 \%$ & {$[38]$} \\
\hline Wuhan, China/140 patients & $17 / 140(12.1 \%)$ & $13.8 \%$ vs. $11.0 \%(P=0.615)$ & - & [39] \\
\hline Wuhan, China/138 patients & $14 / 138(10.1 \%)$ & $22.2 \%$ vs. $5.9 \%$ & - & {$[40]$} \\
\hline Shanghai, China $/ 51$ patients & $3 / 51(6 \%)$ & - & - & [41] \\
\hline Wuhan, China/137 patients & $14 / 137(10.2 \%)$ & - & - & {$[42]$} \\
\hline Wuhan, China/191 patients & $36 / 191(19 \%)$ & $\begin{array}{l}31 \% \text { vs. } 14 \% \text { (non-survivors vs. } \\
\text { survivors) } \\
\text { Univariate OR for in-hospital } \\
\text { death: } 2.85 \text { for diabetes, } \\
\text { disappeared in multivariable } \\
\text { analysis }\end{array}$ & - & {$[43]$} \\
\hline Wuhan, China/201 patients & $22 / 201(10.9 \%)$ & $\begin{array}{l}19.0 \% \text { vs. } 5.1 \% \text { (ARDS vs. no } \\
\text { ARDS) } \\
25.0 \text { vs. } 12.5 \% \text { (non-survivors } \\
\text { vs. survivors, } P=0.15 \text { ) } \\
\text { HR for ARDS in bivariate Cox } \\
\text { regression analysis: } 2.34 \text { for } \\
\text { diabetes, } 1.13 \text { per } 1 \mathrm{mmol} / \mathrm{L} \\
\text { increase in glucose levels }\end{array}$ & $\begin{array}{l}\text { Median (interquartile range) of glucose } \\
\text { (mmol/L): } 6.0(5.00-7.95) \\
\text { Median glucose (mmol/L): } 7.4 \text { vs. } 5.4 \\
\text { (ARDS vs. no ARDS) } \\
\text { Median glucose (mmol/L): } 7.1 \text { vs. } 7.8 \\
\text { (non-survivors vs. survivors, } P=0.92 \text { ) }\end{array}$ & [44] \\
\hline Wuhan, China/174 patients & $37 / 174(21.2 \%)$ & $\begin{array}{l}\text { All parameters were signifi- } \\
\text { cantly higher in patients with } \\
\text { diabetes } \\
\text { Mortality higher in patient with } \\
\text { diabetic complications }\end{array}$ & - & {$[45]$} \\
\hline $\begin{array}{l}\text { Chinese CDC/72,314 cases }(44,672 \\
\text { confirmed, } 16,186 \text { suspected, } \\
10,567 \text { clinically diagnosed, } \\
889 \text { asymptomatic) }\end{array}$ & - & $\begin{array}{l}\text { Overall CFR: } 2.3 \% \\
\text { CFR in diabetes: } 7.3 \%\end{array}$ & - & {$[46]$} \\
\hline $\begin{array}{l}\text { Wuhan, China/29 inpatients with } \\
\text { diabetes }\end{array}$ & - & - & $\begin{array}{l}\text { Among } 881 \text { capillary blood glucose } \\
\text { tests, } 56.6 \% \text { showed abnormal results: } \\
29.4 \% \text { of preprandial blood glucose } \\
\text { tests, and } 69 \% \text { of postprandial blood } \\
\text { glucose tests showed abnormal results; } \\
10.3 \% \text { of the patients experienced at } \\
\text { least one episode of hypoglycemia }\end{array}$ & {$[47]$} \\
\hline Korea/75 mortality cases & $\begin{array}{l}35 \text { had endocrine disease } \\
\text { including diabetes, } \\
\text { hypothyroidism, etc. } \\
\text { out of } 75(46.7 \%)\end{array}$ & - & - & {$[48]$} \\
\hline
\end{tabular}

(Continued to the next page) 


\begin{tabular}{|c|c|c|c|c|}
\hline Country/no. of patients analyzed & $\begin{array}{c}\text { Proportion of patients } \\
\text { with diabetes in the total } \\
\text { population }\end{array}$ & $\begin{array}{l}\text { Proportion of severe vs. } \\
\text { non-severe patients with } \\
\text { diabetes }\end{array}$ & Glycemic status or HbA1c levels & Reference \\
\hline $\begin{array}{l}\text { Korea CDC-operated NNDSS, } \\
\text { Korea/66 fatal cases }\end{array}$ & $23 / 66(36.5 \%)$ & - & - & [49] \\
\hline Korea CDC, Korea/54 mortality cases & $16 / 54(29.6 \%)$ & - & - & {$[50]$} \\
\hline KNCCMC, Korea/28 patients & $2 / 28(7.1 \%)$ & - & - & {$[51]$} \\
\hline $\begin{array}{l}\text { CDC COVID-19 Response Team, } \\
\text { USA/74,439 patients }\end{array}$ & $784(10.9 \%)$ & $\begin{array}{l}32 \%, 24 \% \text {, and } 6 \% \text { in ICU- } \\
\text { admitted, hospitalized (non- } \\
\text { ICU), and non-hospitalized } \\
\text { patients }\end{array}$ & - & [52] \\
\hline Italy/patient number not given & $33.9 \%$ & - & - & {$[53]$} \\
\hline Meta-analysis/46,248 patients & $9 \%$ & $\begin{array}{l}\text { OR }(95 \% \mathrm{CI}) \text { for severe vs. } \\
\text { non-severe status: } 2.07 \\
(0.89-4.82)\end{array}$ & - & {$[54]$} \\
\hline Meta-analysis in China/1,527 patients & $9.7 \%$ & $\begin{array}{l}\text { RR (95\% CI) for ICU vs. non- } \\
\text { ICU: } 2.21(0.88-5.57)\end{array}$ & - & {$[55]$} \\
\hline
\end{tabular}

the European Society of Cardiology and the American College of Cardiology/American Heart Association have recommended that these patients should continue treatment with their usual antihypertensive therapy $[16,61]$.

Poor glycemic control should also be considered as a potential risk factor affecting the prognosis of COVID-19, although it has not yet been established whether poor glycemic control in uninfected patients with diabetes could increase their susceptibility to COVID-19. Furthermore, there are limited data on the association between good glucose control and a favorable prognosis. Surprisingly, none of the studies presenting information on COVID-19 patients with diabetes reported patients' mean hemoglobin $\mathrm{A} 1 \mathrm{c}(\mathrm{HbA} 1 \mathrm{c})$ levels, and few studies reported their mean glucose levels, which means that glycemic control has not been considered as a determinant of patients' prognosis (Table 1).

In this regard, international associations related to diabetes are suggesting strategies for strict glycemic control as a form of self-defense against COVID-19. The American Diabetes Association is providing a platform for health professionals to share and discuss their experiences with COVID-19 and diabetes and to share relevant sources [62]. The Korean Diabetes Association (KDA) released a proposal for the government on prioritizing COVID-19 screening in patients with diabetes who are 70 years or older based on recent data demonstrating that a high propor- tion of COVID-19 patients in Korea have diabetes [63]. In addition, the KDA proposed recommendations for patients with diabetes regarding general hygiene, self-protection against the virus, and self-management rules for glycemic control in the COVID-19 emergency situation. The US Centers for Disease Control and Prevention also included patients with diabetes among the groups at a higher risk for severe illness after COVID-19 infection and requested that special attention be paid to these patients [7].

It is now obvious that diabetes is a clear risk factor for a poor prognosis in COVID-19 patients, and that patients with diabetes are more susceptible to COVID-19 than individuals without diabetes. As strict glycemic control is vitally important for improving the prognosis of patients with diabetes who contract any kind of infectious disease, it is mandatory to check glucose and HbAlc levels in COVID-19 patients with diabetes. In addition, we should instruct patients with diabetes to continue their usual care, both for diabetes and for any comorbidities such as hypertension and cardiovascular disease in order to reduce their cardiovascular risk, as cardiovascular disease was ranked as the toptier risk factor for a poor prognosis of COVID-19 in some reports [54]. Patients should be encouraged to measure their blood glucose levels more frequently than usual in this situation, and to control their diet and continue physical activity as usual while 
maintaining social distancing (e.g., through home training).

Hospitals and governments should prioritize COVID-19 testing in patients with diabetes ahead of other people without underlying diseases. If they are confirmed to have COVID-19, blood glucose monitoring should be more strictly performed, both in the hospital setting and in self-quarantine. In addition, physicians should check their patients' HbAlc levels once they are admitted to the hospital and look for ways to optimize their glycemic control as a way to improve their prognosis. Insulin therapy should be actively considered in COVID-19-infected patients, since infection is a known stressor, and the increased release of counter-regulatory hormones could increase blood glucose levels even in patients who have good glycemic control at other times.

\section{CONCLUSIONS}

Not many reports have yet investigated the relationships between endocrine diseases and COVID-19. We assume that the health professionals who are involved in treating and caring for patients with COVID-19 are so busy that they have not had enough time to analyze their patients' data, a situation exacerbated by their risk of contracting COVID-19. We appreciate and admire all the efforts of medical doctors, nurses, researchers, laboratory technologists, public officials, and police officers to care for COVID-19 patients, to conduct research to learn more about COVID-19, and to prevent the virus from being further propagated across nations and communities.

Although the whole world is striving to stop this pandemic, this global disaster will continue for a substantial period, since we still have not identified the exact characteristics of the virus. It will take some time to clearly understand the immune reaction to SARS-CoV-2, antibody formation, and the rate of mutation of SARS-CoV-2. It seems that 1 to 2 years will be needed to manufacture and distribute vaccines and antiviral agents targeting SARS-CoV-2. As a consequence, until then, we must remain keen to take good care of our patients with endocrine diseases, such as AI, hypopituitarism, diabetes, and others.

What more can we do in this situation besides providing routine medical care? As we have suggested above, we should be especially cautious when caring for patients who are vulnerable to this viral disease. For that matter, sharing our knowledge with and educating our patients in advance would be a wise strategy to fight this crisis together with our patients. Therefore, via telemedicine, digital health, or in outpatient clinics, we should try to share our knowledge with and inform our patients of what we do and do not know about the disease, and encourage them to take prudent steps to protect themselves from the disease through strict self-hygiene, as well as self-management and lifestyle modifications in patients with diabetes. In addition, patients who are on corticosteroid treatment for diseases such as AI and hypopituitarism should have easy access to endocrinologists whenever they have questions and need help. This is how we, as endocrinologists, can protect both our patients and ourselves safely and wisely. We eagerly hope that in the very near future, we will defeat COVID-19 and return to our ordinary lives with our healthy patients.

\section{CONFLICTS OF INTEREST}

No potential conflict of interest relevant to this article was reported.

\section{ORCID}

Eun-Jung Rhee https://orcid.org/0000-0002-6108-7758

Won-Young Lee https://orcid.org/0000-0002-1082-7592

\section{REFERENCES}

1. Lu R, Zhao X, Li J, Niu P, Yang B, Wu H, et al. Genomic characterisation and epidemiology of 2019 novel coronavirus: implications for virus origins and receptor binding. Lancet 2020;395:565-74.

2. World Health Organization. WHO Director-General's opening remarks at the media briefing on COVID-19-11 March 2020 [Internet]. Geneva: World Health Organization; 2020 [cited 2020 Apr 20]. Available from: https://www.who.int/ $\mathrm{dg} /$ speeches/detail/who-director-general-s-opening-remarks-at-the-media-briefing-on-covid-19---11-march-2020.

3. World Health Organization. Coronavirus disease 2019 (COVID-19) situation report: 84 [Internet]. Geneva: World Health Organization; 2020 [cited 2020 Apr 20]. Available from: https:/www.who.int/docs/default-source/coronaviruse/ situation-reports/20200413-sitrep-84-covid-19.pdf?sfvrs $n=$ 44f511ab_2.

4. Zhou P, Yang XL, Wang XG, Hu B, Zhang L, Zhang W, et al. A pneumonia outbreak associated with a new coronavirus of probable bat origin. Nature 2020;579:270-3.

5. Perlman S. Another decade, another coronavirus. N Engl J Med 2020;382:760-2.

6. van Doremalen N, Bushmaker T, Morris DH, Holbrook 
MG, Gamble A, Williamson BN, et al. Aerosol and surface stability of SARS-CoV-2 as compared with SARS-CoV-1. N Engl J Med 2020;382:1564-7.

7. Centers for Disease Control and Prevention. COVID-19: groups at higher risk for severe illness [Internet]. Atlanta: CDC; 2020 [citd 2020 Apr 20]. Available from: https:// www.cdc.gov/coronavirus/2019-ncov/need-extra-precautions/groups-at-higher-risk.html.

8. Grein J, Ohmagari N, Shin D, Diaz G, Asperges E, Castagna A, et al. Compassionate use of remdesivir for patients with severe COVID-19. N Engl J Med 2020;382:2327-36.

9. Cortegiani A, Ingoglia G, Ippolito M, Giarratano A, Einav S. A systematic review on the efficacy and safety of chloroquine for the treatment of COVID-19. J Crit Care 2020;27:279-83.

10. Luo P, Liu Y, Qiu L, Liu X, Liu D, Li J. Tocilizumab treatment in COVID-19: a single center experience. J Med Virol 2020;92:814-8.

11. Shen C, Wang Z, Zhao F, Yang Y, Li J, Yuan J, et al. Treatment of 5 critically Ill patients with COVID-19 with convalescent plasma. JAMA 2020;323:1582-9.

12. Grenfell R, Drew T. Here's why it's taking so long to develop a vaccine for the new coronavirus [Internet]. Manuka: ScienceAlert; 2020 [cited 2020 Apr 20]. Available from: https:// web.archive.org/web/20200228010631/https://www.sciencealert.com/who-says-a-coronavirus-vaccine-is-18-monthsaway.

13. Thanh Le T, Andreadakis Z, Kumar A, Gomez Roman R, Tollefsen S, Saville M, et al. The COVID-19 vaccine development landscape. Nat Rev Drug Discov 2020;19:305-6.

14. Vaduganathan M, Vardeny O, Michel T, McMurray JJV, Pfeffer MA, Solomon SD. Renin-angiotensin-aldosterone system inhibitors in patients with COVID-19. N Engl J Med 2020; 382:1653-9.

15. Qiao Y, Shin JI, Chen TK, Inker LA, Coresh J, Alexander $\mathrm{GC}$, et al. Association between renin-angiotensin system blockade discontinuation and all-cause mortality among persons with low estimated glomerular filtration rate. JAMA Intern Med 2020;180:718-26.

16. European Society of Cardiology. Position statement of the ESC council on hypertension on ACE-inhibitors and angiotensin receptor blockers [Internet]. Sophia Antipolis: ESC; 2020 [cited 2020 Apr 20]. Available from: https://www.escardio.org/Councils/Council-on-Hypertension-(CHT)/ News/position-statement-of-the-esc-council-on-hypertension-on-ace-inhibitors-and-ang.

17. Bergthorsdottir R, Leonsson-Zachrisson M, Oden A, Jo- hannsson G. Premature mortality in patients with Addison's disease: a population-based study. J Clin Endocrinol Metab 2006;91:4849-53.

18. Erichsen MM, Lovas K, Fougner KJ, Svartberg J, Hauge ER, Bollerslev J, et al. Normal overall mortality rate in Addison's disease, but young patients are at risk of premature death. Eur J Endocrinol 2009;160:233-7.

19. Burman P, Mattsson AF, Johannsson G, Hoybye C, Holmer H, Dahlqvist P, et al. Deaths among adult patients with hypopituitarism: hypocortisolism during acute stress, and de novo malignant brain tumors contribute to an increased mortality. J Clin Endocrinol Metab 2013;98:1466-75.

20. Lee YY, Cho NH, Lee JW, Kim NK, Kim HS, Kim MK. Clinical characteristics of patients with adrenal insufficiency in a general hospital. Endocrinol Metab (Seoul) 2017;32:839.

21. Hong AR, Ryu OH, Kim SY, Kim SW; Korean Adrenal Gland and Endocrine Hypertension Study Group, Korean Endocrine Society. Characteristics of Korean patients with primary adrenal insufficiency: a registry-based nationwide survey in Korea. Endocrinol Metab (Seoul) 2017;32:466-74.

22. Tresoldi AS, Sumilo D, Perrins M, Toulis KA, Prete A, Reddy $\mathrm{N}$, et al. Increased infection risk in addison's disease and congenital adrenal hyperplasia. J Clin Endocrinol Metab 2020;105:418-29.

25. Bancos I, Hazeldine J, Chortis V, Hampson P, Taylor AE, Lord JM, et al. Primary adrenal insufficiency is associated with impaired natural killer cell function: a potential link to increased mortality. Eur J Endocrinol 2017;176:471-80.

24. Edvardsen K, Bjanesoy T, Hellesen A, Breivik L, Bakke M, Husebye ES, et al. Peripheral blood cells from patients with autoimmune addison's disease poorly respond to interferons in vitro, despite elevated serum levels of interferon-inducible chemokines. J Interferon Cytokine Res 2015;35:759-70.

25. Hahner S, Loeffler M, Bleicken B, Drechsler C, Milovanovic D, Fassnacht M, et al. Epidemiology of adrenal crisis in chronic adrenal insufficiency: the need for new prevention strategies. Eur J Endocrinol 2010;162:597-602.

26. Hahner S, Spinnler C, Fassnacht M, Burger-Stritt S, Lang K, Milovanovic D, et al. High incidence of adrenal crisis in educated patients with chronic adrenal insufficiency: a prospective study. J Clin Endocrinol Metab 2015;100:407-16.

27. Bornstein SR, Allolio B, Arlt W, Barthel A, Don-Wauchope A, Hammer GD, et al. Diagnosis and treatment of primary adrenal insufficiency: an Endocrine Society Clinical Practice Guideline. J Clin Endocrinol Metab 2016;101:364-89. 
28. Fareau GG, Vassilopoulou-Sellin R. Hypercortisolemia and infection. Infect Dis Clin North Am 2007;21:639-57.

29. Dekkers OM, Horvath-Puho E, Jorgensen JO, Cannegieter SC, Ehrenstein V, Vandenbroucke JP, et al. Multisystem morbidity and mortality in Cushing's syndrome: a cohort study. J Clin Endocrinol Metab 2013;98:2277-84.

30. Pivonello R, Isidori AM, De Martino MC, Newell-Price J, Biller BM, Colao A. Complications of Cushing's syndrome: state of the art. Lancet Diabetes Endocrinol 2016;4:611-29.

31. Melmed S, Polonsky K, Larsen PR, Kronenberg H. Williams textbook of endocrinology. 13th ed. Philadelphia: Saunders Elsevier; 2016. Chapter 16, The adrenal cortex; p. 489-555.

32. International Diabetes Federation. IDF Diabetes Atlas 9th edition 2019 [Internet]. Brussels: IDF; 2020 [cited 2020 Apr 20]. Available from: https://www.diabetesatlas.org/upload/ resources/material/20191218_144459_2019_global_factsheet.pdf.

33. Yang JK, Feng Y, Yuan MY, Yuan SY, Fu HJ, Wu BY, et al. Plasma glucose levels and diabetes are independent predictors for mortality and morbidity in patients with SARS. Diabet Med 2006;23:623-8.

34. Knapp S. Diabetes and infection: is there a link? A mini-review. Gerontology 2013;59:99-104.

35. Huang C, Wang Y, Li X, Ren L, Zhao J, Hu Y, et al. Clinical features of patients infected with 2019 novel coronavirus in Wuhan, China. Lancet 2020;395:497-506.

36. Chen N, Zhou M, Dong X, Qu J, Gong F, Han Y, et al. Epidemiological and clinical characteristics of 99 cases of 2019 novel coronavirus pneumonia in Wuhan, China: a descriptive study. Lancet 2020;395:507-13.

37. Guan WJ, Ni ZY, Hu Y, Liang WH, Ou CQ, He JX, et al. Clinical characteristics of coronavirus disease 2019 in China. N Engl J Med 2020;382:1708-20.

38. Yang X, Yu Y, Xu J, Shu H, Xia J, Liu H, et al. Clinical course and outcomes of critically ill patients with SARS-CoV-2 pneumonia in Wuhan, China: a single-centered, retrospective, observational study. Lancet Respir Med 2020;8:475-81.

39. Zhang JJ, Dong X, Cao YY, Yuan YD, Yang YB, Yan YQ, et al. Clinical characteristics of 140 patients infected with SARS-CoV-2 in Wuhan, China. Allergy 2020 Feb 19 [Epub]. https://doi.org/10.1111/all.14238.

40. Wang D, Hu B, Hu C, Zhu F, Liu X, Zhang J, et al. Clinical characteristics of 138 hospitalized patients with 2019 novel coronavirus-infected pneumonia in Wuhan, China. JAMA 2020;323:1061-9.
41. Song F, Shi N, Shan F, Zhang Z, Shen J, Lu H, et al. Emerging 2019 novel coronavirus (2019-nCoV) Pneumonia. Radiology 2020;295:210-7.

42. Deng Y, Liu W, Liu K, Fang YY, Shang J, Zhou L, et al. Clinical characteristics of fatal and recovered cases of coronavirus disease 2019 (COVID-19) in Wuhan, China: a retrospective study. Chin Med J (Engl) 2020;133:1261-7.

43. Zhou F, Yu T, Du R, Fan G, Liu Y, Liu Z, et al. Clinical course and risk factors for mortality of adult inpatients with COVID-19 in Wuhan, China: a retrospective cohort study. Lancet 2020;395:1054-62.

44. Wu C, Chen X, Cai Y, Xia J, Zhou X, Xu S, et al. Risk factors associated with acute respiratory distress syndrome and death in patients with coronavirus disease 2019 pneumonia in Wuhan, China. JAMA Intern Med 2020 Mar 13 [Epub]. https://doi.org/10.1001/jamainternmed.2020.0994.

45. Guo W, Li M, Dong Y, Zhou H, Zhang Z, Tian C, et al. Diabetes is a risk factor for the progression and prognosis of COVID-19. Diabetes Metab Res Rev 2020 Mar 31 [Epub]. https://doi.org/10.1002/dmrr.3319.

46. Wu Z, McGoogan JM. Characteristics of and important lessons from the coronavirus disease 2019 (COVID-19) outbreak in China: summary of a report of 72314 cases from the Chinese center for disease control and prevention. JAMA 2020;323:1239-42.

47. Zhou J, Tan J. Diabetes patients with COVID-19 need better blood glucose management in Wuhan, China. Metabolism 2020;107:154216.

48. Kang YJ. Mortality rate of infection with COVID-19 in Korea from the perspective of underlying disease. Disaster Med Public Health Prep 2020 Mar 31 [Epub]. https://doi.org/ 10.1017/dmp.2020.60.

49. COVID-19 National Emergency Response Center, Epidemiology and Case Management Team, Korea Centers for Disease Control and Prevention. Coronavirus disease-19: the first 7,755 cases in the Republic of Korea. Osong Public Health Res Perspect 2020;11:85-90.

50. Korean Society of Infectious Diseases and Korea Centers for Disease Control and Prevention. Analysis on 54 mortality cases of coronavirus disease 2019 in the Republic of Korea from January 19 to March 10, 2020. J Korean Med Sci 2020; 35:e132.

51. Kim ES, Chin BS, Kang CK, Kim NJ, Kang YM, Choi JP, et al. Clinical course and outcomes of patients with severe acute respiratory syndrome coronavirus 2 infection: a preliminary report of the first 28 patients from the Korean co-

Copyright (C) 2020 Korean Endocrine Society 
hort study on COVID-19. J Korean Med Sci 2020;35:e142.

52. CDC COVID-19 Response Team. Preliminary estimates of the prevalence of selected underlying health conditions among patients with coronavirus disease 2019: United States, February 12-March 28, 2020. MMWR Morb Mortal Wkly Rep 2020;69:382-6.

53. Gentile S, Strollo F, Ceriello A. COVID-19 infection in Italian people with diabetes: lessons learned for our future (an experience to be used). Diabetes Res Clin Pract 2020;162:108137.

54. Yang J, Zheng Y, Gou X, Pu K, Chen Z, Guo Q, et al. Prevalence of comorbidities in the novel Wuhan coronavirus (COVID-19) infection: a systematic review and meta-analysis. Int J Infect Dis 2020;94:91-5.

55. Li B, Yang J, Zhao F, Zhi L, Wang X, Liu L, et al. Prevalence and impact of cardiovascular metabolic diseases on COVID-19 in China. Clin Res Cardiol 2020;109:531-8.

56. Roca-Ho H, Riera M, Palau V, Pascual J, Soler MJ. Characterization of ACE and ACE2 expression within different organs of the NOD mouse. Int J Mol Sci 2017;18:563.

57. Wysocki J, Ye M, Soler MJ, Gurley SB, Xiao HD, Bernstein $\mathrm{KE}$, et al. ACE and ACE2 activity in diabetic mice. Diabetes 2006;55:2132-9.

58. Rao S, Lau A, So HC. Exploring diseases/traits and blood proteins causally related to expression of ACE2, the putative receptor of 2019-nCov: a Mendelian randomization analysis. medRxiv 2020 Mar 8. Available from: https://www.medrxiv.org/content/10.1101/2020.03.04.20031237v1.

59. Fang L, Karakiulakis G, Roth M. Are patients with hypertension and diabetes mellitus at increased risk for COVID-19 infection? Lancet Respir Med 2020;8:e21.

60. Wan Y, Shang J, Graham R, Baric RS, Li F. Receptor recognition by the novel coronavirus from Wuhan: an analysis based on decade-long structural studies of SARS coronavirus. J Virol 2020;94:e00127-20.

61. Bavishi C, Maddox TM, Messerli FH. Coronavirus disease 2019 (COVID-19) infection and renin angiotensin system blockers. JAMA Cardiol 2020 Apr 3 [Epub]. https://doi. org/10.1001/jamacardio.2020.1282.

62. American Diabetes Association. Diabetes and COVID-19 [Internet]. Arlington: ADA; 2020 [cited 2020 Apr 20]. Available from: https://procommunity.diabetes.org/forums/community-home?CommunityKey=e650b3b6-bf37-4f1f-af43edc5dce1895b.

63. Korean Diabetes Association. A proposal from Korean Diabetes Association on endemic of COVID-19 in Korea [Internet]. Seoul: KDA; 2020 [cited 2020 Apr 20]. Available from: https://www.diabetes.or.kr/pro/news/index.php?code $=$ board\&number $=1859 \&$ mode $=$ view. 